Article

\title{
Synthesis and Characterization of the Conducting Polymer Micro-Helix Based on the Spirulina Template
}

\author{
Xiao-Yu Hu ${ }^{1,2}{ }^{\mathbb{D}}$, Jun Ouyang ${ }^{1}$, Guo-Chang Liu ${ }^{1}$, Meng-Juan Gao ${ }^{1}$, Lai-Bo Song ${ }^{1}$, \\ Jianfeng Zang ${ }^{3}$ and Wei Chen ${ }^{1, *}$ \\ 1 College of Life Science and Technology, Huazhong University of Science and Technology, Wuhan 430074, \\ China; 13971144169@139.com (X.-Y.H.); m201571649@hust.edu.cn (J.O.); d201577407@hust.edu.cn (G.-C.L.); \\ m201671630@hust.edu.cn (M.-J.G.); m201771732@hust.edu.cn (L.-B.S.) \\ 2 Hubei Boffin Technology Co. Ltd., Wuhan 430074, China \\ 3 Innovation Institute, Huazhong University of Science and Technology, Wuhan 430074, China; \\ jfzang@hust.edu.cn \\ * Correspondence: chen1980wei@hust.edu.cn; Tel.: +86-027-87792202
}

Received: 25 May 2018; Accepted: 5 August 2018; Published: 7 August 2018

check for updates

\begin{abstract}
As one of the most interesting naturally-occurring geometries, micro-helical structures have attracted attention due to their potential applications in fabricating biomedical and microelectronic devices. Conventional processing techniques for manufacturing micro-helices are likely to be limited in cost and mass-productivity, while Spirulina, which shows natural fine micro-helical forms, can be easily mass-reproduced at an extremely low cost. Furthermore, considering the extensive utility of conducting polymers, it is intriguing to synthesize conducting polymer micro-helices. In this study, PPy (polypyrrole), PANI (polyaniline), and PEDOT (poly(3,4-ethylenedioxythiophene)) micro-helices were fabricated using Spirulina platensis as a bio-template. The successful formations of the conducting polymer micro-helix were confirmed using scanning electron microscopy (SEM). Fourier transform infrared spectroscopy (FTIR) and Raman and X-ray diffraction (XRD) were employed to characterize the molecular structures of the conducting polymer in micro-helical forms. In the electrochemical characterization, the optimized specific capacitances for the PPy micro-helix, the PANI micro-helix, and the PEDOT micro-helix were found to be $234 \mathrm{~F} / \mathrm{g}, 238 \mathrm{~F} / \mathrm{g}$ at the scan rate of $5 \mathrm{mV} / \mathrm{s}$, and $106.4 \mathrm{~F} / \mathrm{g}$ at the scan rate of $10 \mathrm{mV} / \mathrm{s}$, respectively. Therefore, it could be expected that other conducting polymer micro-helices with Spirulina as a bio-template could be also easily synthesized for various applications.
\end{abstract}

Keywords: PPy micro-helix; PANI micro-helix; PEDOT micro-helix; Spirulina; bio-template; conducting polymer

\section{Introduction}

Due to their underlying chemical and physical functions, the helical structure is one of the most interesting geometries discovered in many biomolecules and bio-structures, such as the $\alpha$-helix structure in protein, dsDNA, virus, bacteria, spiral vessels, tendrils, etc. [1]. Inspired by these naturally-occurring structures, considerable efforts have been made to design and fabricate various microscale or nanoscale helix-based devices, such as micromotors [2-8], circular polarizers [9], force sensors [10-12], actuators [13,14], and artificial muscles [15,16]. Furthermore, the theoretical calculations on helix-based materials have also predicted other possible applications including catalysis [17], plasmonics [18], circular dichroism [19], and reflection [20].

In order to generate helical micro/nano-structures, various techniques, including molecular self-assembly, electrospinning [21], photolithography [22], mechanical twisting [23], microfluidics [1,24], 
and oblique angle-based deposition [25] have been developed. However, it is still difficult to realize the large-scale production of a uniform helix at a low cost since most of these techniques are based on delicate conditions and sophisticated equipment [26]. Thus, the high requirements for these fabrication approaches are expected to limit their practical applications. On the one hand, there are plenty of highly-ordered biological structures in a wide range of dimensions and patterns that can be employed as templates [27]. For micro-sized helix synthesis, two kinds of biological templates have mainly been used: one is from xylem vessels that are composed of chiral crystalline cellulose and widely distributed in almost every part of vascular plants [28], and the other is from Spirulina that grows naturally in a helical shape and has already been commercialized as food supplements [29]. Though xylem-originated helical microstructures are abundant in a wide variety of plants, the difficulty in the isolation process of the spiral vessels through chemical methods still exist [28]. In contrast, Spirulina that is in a perfect helical shape can be easily cultured and extracted in large quantities by simple filtration. Until now, Spirulina-based templates have successfully contributed to the synthesis of the magnetic helix [4,30], silica helix [31], copper helix [32-34], Ni-Fe-P alloy helix [35], and silver helix [36].

On the other hand, conducting polymers, such as polypyrrole (PPy), polyaniline (PANI), poly(3,4-ethylenedioxythiophene) (PEDOT), polythiophene (PTh), and poly( $p$-phenylenevinylene) (PPV) have been widely fabricated or integrated into micro/nanostructure-based devices for the applications of flexible supercapacitors [37,38], biofuel cells [39], artificial muscles [40], tissue scaffolds [41], artificial synapses [42], smart textiles [43], etc. The conducting polymers in helical micro/nanostructures have also been reported using both template- and non-template-based methods [21,44,45]. Among these methods, the templates are critical for the fabrication of highly-ordered helical microstructures of the conducting polymers [45-48]. Thus, it will be interesting and worthy to utilize Spirulina as a helical bio-templates which can be easily reproduced en masse and with low cost.

In this article, Spirulina-templated conducting polymer micro-helices, including PPy micro-helix, PANI micro-helix, and PEDOT micro-helix, were successfully synthesized by in situ polymerization using $\mathrm{FeCl}_{3}$ as an oxidant. The morphologies, molecular structures, and electrical and electrochemical properties of the conducting polymer micro-helices were characterized by SEM, FTIR, Raman, XRD, four-point probes, CV, and EIS, respectively.

\section{Materials and Methods}

\subsection{Materials}

Spirulina platensis (FACHB-439) was purchased from the Institute of Hydrobiology, Chinese Academy of Sciences (Wuhan, China). Figure 1 shows the optical microscope image of Spirulina platensis in its natural form and its wire diameter, diameter of helix, pitch, turn number, free length, and pitch angle are observed to be about $5-7,20-25,24-30,8-16,176-780 \mu \mathrm{m}$ and $90^{\circ}-120^{\circ}$, respectively. A modified Zarrouk medium for Spirulina cultivation contained $13.61 \mathrm{~g} / \mathrm{L}$ sodium bicarbonate $\left(\mathrm{NaHCO}_{3}\right), 4.03 \mathrm{~g} / \mathrm{L}$ sodium carbonate $\left(\mathrm{Na}_{2} \mathrm{CO}_{3}\right), 0.50 \mathrm{~g} / \mathrm{L}$ dipotassium hydrogenphosphate $\left(\mathrm{K}_{2} \mathrm{HPO}_{4}\right), 2.50 \mathrm{~g} / \mathrm{L}$ sodium nitrate $\left(\mathrm{NaNO}_{3}\right), 1.00 \mathrm{~g} / \mathrm{L}$ potassium sulfate $\left(\mathrm{K}_{2} \mathrm{SO}_{4}\right), 1.00 \mathrm{~g} / \mathrm{L}$ sodium chloride $(\mathrm{NaCl}), 0.20 \mathrm{~g} / \mathrm{L}$ magnesium sulfate heptahydrate $\left(\mathrm{MgSO}_{4} \cdot 7 \mathrm{H}_{2} \mathrm{O}\right), 0.04 \mathrm{~g} / \mathrm{L}$ calcium chloride dehydrate $\left(\mathrm{CaCl}_{2} \cdot 2 \mathrm{H}_{2} \mathrm{O}\right), 0.01 \mathrm{~g} / \mathrm{L}$ ferrous sulfate heptahydrate $\left(\mathrm{FeSO}_{4} \cdot 7 \mathrm{H}_{2} \mathrm{O}\right), 2.86 \mu \mathrm{g} / \mathrm{L}$ orthoboric acid $\left(\mathrm{H}_{3} \mathrm{BO}_{3}\right), 1.86 \mu \mathrm{g} / \mathrm{L}$ manganese chloride tetrahydrate $\left(\mathrm{MnCl}_{2} \cdot 4 \mathrm{H}_{2} \mathrm{O}\right), 0.22 \mu \mathrm{g} / \mathrm{L}$ zinc sulphate heptahydrate $\left(\mathrm{ZnSO}_{4} \cdot 7 \mathrm{H}_{2} \mathrm{O}\right), 0.39 \mu \mathrm{g} / \mathrm{L}$ sodiummolybdate dehydrate $\left(\mathrm{Na}_{2} \mathrm{MoO}_{4} \cdot 2 \mathrm{H}_{2} \mathrm{O}\right)$, $0.08 \mu \mathrm{g} / \mathrm{L}$ copper(II) sulfate pentahydrate $\left(\mathrm{CuSO}_{4} \cdot 5 \mathrm{H}_{2} \mathrm{O}\right)$, and $0.05 \mu \mathrm{g} / \mathrm{L}$ cobaltous nitrate hexahydrate $\left(\mathrm{Co} .\left(\mathrm{NO}_{3}\right)_{2} \cdot 6 \mathrm{H}_{2} \mathrm{O}\right)$. Additionally, all these reagents were bought from Sinopharm Chemical Reagent Co., Ltd. (Shanghai, China). Pyrrole, aniline, and 3,4-ethylenedioxythiophene were purchased from the Aladdin Industrial Corporation (Shanghai, China). Polytetrafluoroethylene with an average particle size of $5 \mu \mathrm{m}$ was purchased from Shanghai Macklin Biochemical Co. Ltd. (Shanghai, China). Nickel foam $(99.8 \% \mathrm{Ni})$ and acetylene black (battery grade) were purchased from the Taiyuan Liyuan Lithium 
Technology Center Co. Ltd. (Taiyuan, China). Deionized water $(18.2 \mathrm{M} \Omega \cdot \mathrm{cm}$, Milli-Q Reference, Merck Millipore, Shanghai, China) was used throughout the experiments.

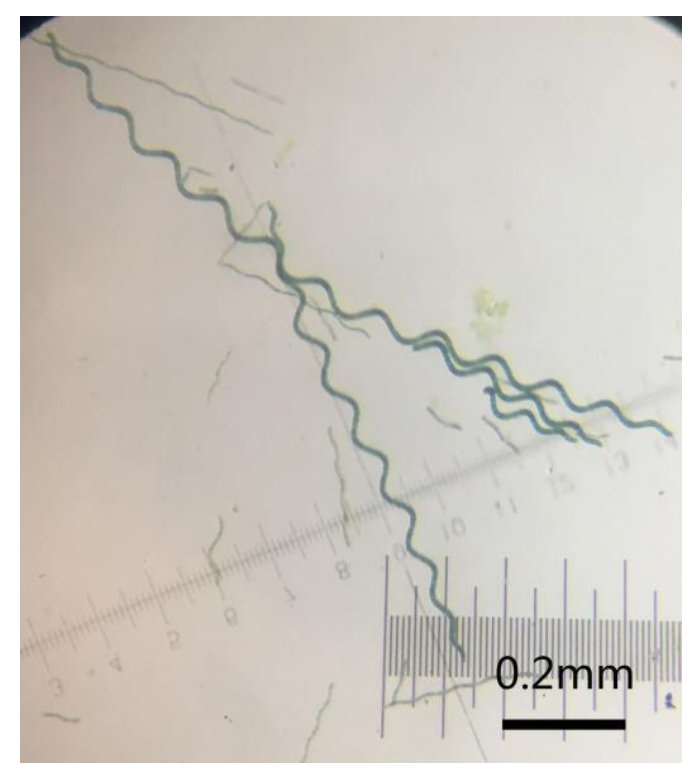

Figure 1. The optical microscope images of Spirulina cells.

\subsection{Methods}

\subsubsection{Cultivation and Preparations of Spirulina platensis}

The cultivation of the Spirulina started with the initial inoculum density of 0.1 with magnetic stirring in an illumination incubator (Ningbo Yanghui instrument Co., Ltd., Ningbo, China) at $36 \pm 1{ }^{\circ} \mathrm{C}$ in $12 / 12 \mathrm{~h}$ light-dark cycles. When the inoculum density was above 1.2 after 12 days of cultivation, the Spirulina was collected by a 350-mesh nylon filter and rinsed with $0.9 \% w / w$ sodium chloride solution three times. The tissue fixation of the Spirulina was carried out in 1:9 $v / v$ glutaraldehyde aqueous solution for $6 \mathrm{~h}$ to maintain the bio-helix form. After the fixation, the unreacted glutaraldehyde was rinsed out with $0.01 \mathrm{M}$ phosphate-buffered solution (PBS) and deionized water, successively. Fixed Spirulina template suspension was used throughout the experiments.

\subsubsection{Fabrication of the Spirulina-Templated PPy Helical Microstructure}

For the fabrication of Spirulina-templated PPy helical microstructure, $11 \mathrm{~g}$ of Spirulina template was suspended in a $50 \mathrm{~mL}$ solution containing $0.1 \mathrm{M} \mathrm{HCl}$ and $0.2 \mathrm{M}$ pyrrole by magnetic stirring at $300 \mathrm{rpm}$ for $0.5 \mathrm{~h}$. For PPy polymerization, $50 \mathrm{~mL}$ of $0.6 \mathrm{M} \mathrm{FeCl}_{3}$ solution was slowly added into the suspension and reacted for $6 \mathrm{~h}$. After the polymerization, the suspension was filtered by a 350-mesh nylon filter and rinsed with $0.1 \mathrm{M} \mathrm{HCl}$ to remove the loosely bound or uncoated PPy. Finally, the PPy micro-helix was dried in an oven at $50{ }^{\circ} \mathrm{C}$ for $6 \mathrm{~h}$.

\subsubsection{Fabrication of the Spirulina-Templated PANI Helical Microstructure}

For the fabrication of Spirulina-templated PANI helical microstructure, $12 \mathrm{~g}$ of Spirulina template was suspended in $160 \mathrm{~mL}$ of water containing $0.5 \mathrm{M}$ aniline by magnetic stirring at $300 \mathrm{rpm}$ for $1 \mathrm{~h}$. The aniline adsorbed Spirulina cells were added into $150 \mathrm{~mL}$ of $0.5 \mathrm{M} \mathrm{FeCl}_{3}$ solution and reacting overnight with magnetic stirring. After the polymerization, the suspension was filtered by a 350-mesh nylon filter and sonicated in ethanol to dislodge loosely bound or free polymers. The suspension was then washed with $0.1 \mathrm{M} \mathrm{HCl}$ and deionized water, successively. Finally, the PANI micro-helix was dried in an oven at $50{ }^{\circ} \mathrm{C}$ for $6 \mathrm{~h}$. 


\subsubsection{Fabrication of the Spirulina-Templated PEDOT Helical Microstructure}

For the fabrication of Spirulina-templated PEDOT helical microstructure, $30 \mathrm{~mL}$ of a suspension containing $2.5 \mathrm{~g}$ of Spirulina template, $0.23 \mathrm{M}$ 3,4-ethylenedioxythiophene (EDOT), $2.34 \mathrm{M} \mathrm{FeCl}_{3} \cdot 6 \mathrm{H}_{2} \mathrm{O}$, and $0.12 \mathrm{M} p$-toluenesulfonic acid monohydrate were mixed. For the PEDOT polymerization, the suspension was sonicated in an ultrasonic washer for $1 \mathrm{~h}$. After the polymerization, the suspension was filtered by a 350-mesh nylon filter and washed with deionized water and pure ethanol successively to remove the loosely bound or free polymers. Finally, the PEDOT micro-helix was dried in an oven at $50{ }^{\circ} \mathrm{C}$ for $6 \mathrm{~h}$.

\subsubsection{Preparations of PPy, PANI, and PEDOT Helix Modified Electrodes}

The PPy, PANI, and PEDOT micro-helix powders, acetylene black, and poly(tetrafluoroethylene) (PTFE) were mixed by the mass ratio of 8:1:1, and ground homogeneously with the addition of pure ethanol, respectively. For each conducting polymer micro-helix, about $0.01 \mathrm{~g}$ of the mixture was coated onto a nickel foam sheet in the size of $1 \mathrm{~cm} \times 1 \mathrm{~cm}$ and oven-dried at $60^{\circ} \mathrm{C}$ overnight.

\subsection{Characterizations}

\subsubsection{Morphology Analysis}

The morphology of Spirulina platensis in its natural form was observed using an optical microscope (SMARTR, Chongqing Ott optical instruments Co., Ltd., Chongqing, China). The morphologies of the PPy micro-helix, PANI micro-helix, and PEDOT micro-helix were observed using a field emission scanning electron microscope (FESEM) (Helios NanoLab G3, FEI Company, Brno, Czech Republic and Nova Nano SEM 450, FEI Company, Eindhoven, The Netherlands) with the accelerating voltages of 2 and $10 \mathrm{kV}$.

\subsubsection{Fourier Transform Infrared Spectroscopy (FTIR)}

A Fourier transform infrared spectrometer (Vertex 70, Bruker Corporation, Karlsruhe, Germany) was used to obtain the FTIR spectra of the PPy, PANI, and PEDOT micro-helices with a scanning range of $400-4000 \mathrm{~cm}^{-1}$ at a resolution of $1.93 \mathrm{~cm}^{-1}$ at room temperature. The sample tablets were prepared by mixing the sample powders with $5 \%(w / w)$ potassium bromide $(\mathrm{KBr})$.

\subsubsection{Raman Spectroscopy}

A confocal laser Raman spectrometer (LabRAM HR800, Horiba Jobin Yvon, Paris, France and Renishaw inVia plus, Renishaw plc, Gloucestershire, United Kingdom) was employed to obtain a Raman Spectroscopy of the PPy, PANI, and PEDOT micro-helices. Raman spectra were acquired with a $532 \mathrm{~nm}$ excitation laser source with a power of $1.8 \mathrm{~mW}$ in the range of $500-2000 \mathrm{~cm}^{-1}$.

\subsubsection{X-ray Diffraction (XRD)}

An X-ray diffraction meter (Empyrean XRD, Malvern Panalytical Ltd., Malvern, UK) was used to determine the atomic and molecular structure of the PPy, PANI, and PEDOT micro-helices. The XRDs were conducted with a $\mathrm{Cu} K$-Alpha radiation source with a step size of $0.01313^{\circ}$ in the scanning range of $5^{\circ}-50^{\circ}$ and wavelength of $1.540598 \AA$.

\subsubsection{Electrochemical Characterization}

The sheet resistance of each conducting polymer micro-helix was measured in three different areas, three times by four-point probes (ST2263 digital four-point probes, Suzhou Jingge Electronic Co., Ltd., Suzhou, China). Cyclic voltammetry (CV) and electrochemical impedance spectroscopy (EIS) of the PPy, PANI, and PEDOT micro-helix-modified electrodes were conducted on a CS 1350 electrochemical workstation (Wuhan Corrtest Instrument Co., Ltd., Wuhan, China) with a three-electrode cell in which 
a Pt foil $(1 \mathrm{~cm} \times 1 \mathrm{~cm})$ and $\mathrm{Ag} / \mathrm{AgCl}$ electrode were used as a counter electrode and reference electrode, respectively. In CV measurements, ten cycles between -0.3 and $0.7 \mathrm{~V}$ in $0.1 \mathrm{M} \mathrm{Na}_{2} \mathrm{SO}_{4}$ at scan rates of $5,10,20,30,50$, and $100 \mathrm{mV} / \mathrm{s}$ were performed. EIS measurements were performed in the frequency range of $10^{5}$ to $0.01 \mathrm{~Hz}$ at an open circuit potential with an $\mathrm{AC}$ perturbation of $10 \mathrm{mV}$, and the data were analyzed by ZView software (Wuhan Corrtest Instrument Co., Ltd., Wuhan, China).

\section{Results and Discussion}

\subsection{Morphologies of PPy, PANI, and PEDOT Micro-Helices}

In Figure 2a, the distinct display of the helix micro-structures without any metal sputtering coatings confirmed that conductive PPy has been successfully formed on the surface of Spirulina and the coating process showed no adverse effect on the initial helical shape of Spirulina. In Figure $2 b$, it can be observed that the cross-section of the PPy micro-helix has a solid and compact interior which has a diameter of about $7.3 \mu \mathrm{m}$ and a relatively thin outer layer with about $0.3 \mu \mathrm{m}$ thickness. The appearance of this solid interior is interesting because both the hollow and the solid helical structures have been observed on Cu-coated Spirulina and Ag-coated Spirulina by electroless plating [32,34,36]. This solid interior of the helical structure should be composed of the fixed cytoplasmic components from glutaraldehyde treatment because it also existed in the Spirulina templates without PPy coating. This difference between the hollow and solid interiors may result from the Spirulina template preparation process. In the hollow helical structure formation, the drying process vaporized the moisture of Spirulina and the volume of Spirulina shrunk to form the hollow helical structure [34], while in our preparation, no drying process was included. PPy coating shows a typical granular raspberry morphology and a fully-encapsulated Spirulina surface [49]. As no bare Spirulina can be observed and the PPy layers fully covered on all these helical template surfaces, it can be speculated that there exists a chemical bonding between PPy and the Spirulina surface. As one genre of cyanobacteria, Spirulina is also covered by the external surface layers that are composed of 2D crystalline arrays of glycoprotein (S-layers) and carbohydrate structures [50,51]. Though the compositions of these carbohydrate structures may vary with the species of cyanobacteria, they mainly include monosaccharides and polysaccharides, such as cellulose-like homoglucan, xyloglucan, uronic acid, glucose, xylose, and ribose [52]. Therefore, this bonding is likely to be hydrogen bonding that is from the interaction between the hydroxyl groups of the saccharides in the Spirulina cell wall and the $\mathrm{H}$ of the $\mathrm{N}$ and/or the $\mathrm{N}$ in the pyrrole ring [53]. Figure 2c shows that the Spirulina templates were not only enwrapped, but also bounded with each other by PANI. Though aniline monomers are likely to initiate the polymerization on the hydroxyl groups of the saccharides on the Spirulina surface, the free PANI seems to be easily formed between the spaces of the Spirulina templates, as shown in Figure 2d. This result may be due to the relatively high aniline monomer concentration since the morphology of the PANI-coated cotton fiber was also monomer concentration-dependent [54]. In Figure 2e, it can be seen that the Spirulina templates were coated with an uneven granular PEDOT and their cross-sections also showed solid and compact interiors since they had the same preparation process as that of the PPy micro-helix. In Figure 2f, a rougher surface of PEDOT micro-helix can be found in comparison with the PPy and PANI micro-helix surfaces. This morphology may suggest that there exists the weakest interaction between the PEDOT and Spirulina surfaces among these three conducting polymers. 


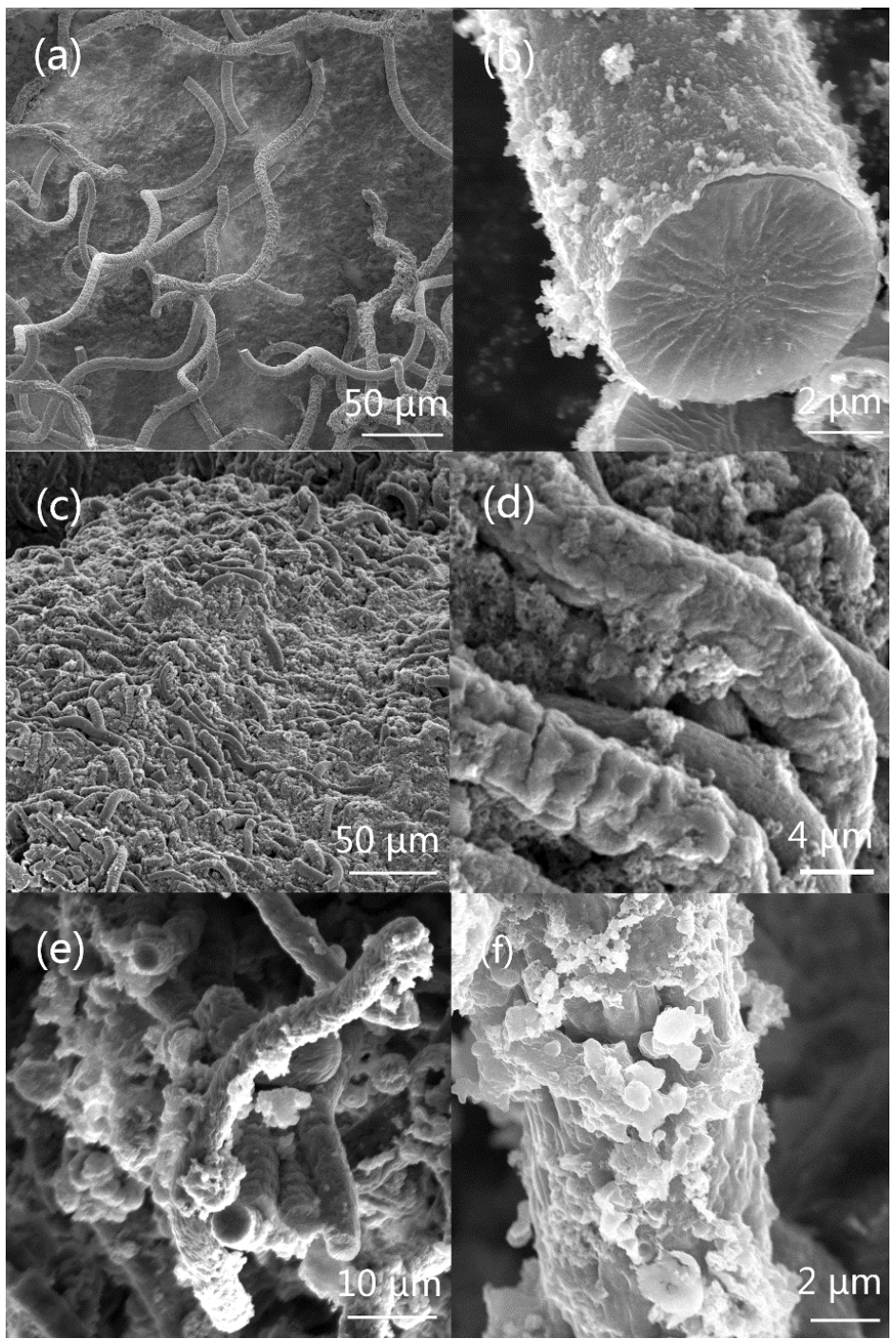

Figure 2. The scanning electron microscopy (SEM) images of polypyrrole (PPy) micro-helix (a,b); polyaniline (PANI) micro-helix (c,d); and poly(3,4-ethylenedioxythiophene) (PEDOT) micro-helix (e,f).

\subsection{Fourier Transform Infrared Spectroscopy (FTIR) Analysis}

In Figure 3a, the broad band at around $3432 \mathrm{~cm}^{-1}$ of raw Spirulina was assigned to -OH groups of glucose and $-\mathrm{NH}$ groups of protein $[55,56]$. The bands at 2959,2928 , and $2874 \mathrm{~cm}^{-1}$ correspond to lipid methyl $\left(-\mathrm{CH}_{3}\right)$ asymmetric stretching, lipid methylene $\left(-\mathrm{CH}_{2}\right)$ asymmetric stretching, and protein methyl $\left(-\mathrm{CH}_{3}\right)$ symmetric stretching, respectively [57]. The bands at 1655,1542 , and $1453 \mathrm{~cm}^{-1}$ can be assigned to $\mathrm{C}=\mathrm{O}$ stretching, and $\mathrm{N}-\mathrm{H}$ inner and outer bending, respectively $[55,58]$. The bands at 1396 , $1241,1154,1079$, and $1031 \mathrm{~cm}^{-1}$ can be attributed to $\mathrm{C}-\mathrm{O}, \mathrm{C}-\mathrm{C}$ stretching vibrations of protein, fatty acids, and saccharides, respectively $[57,59]$. 

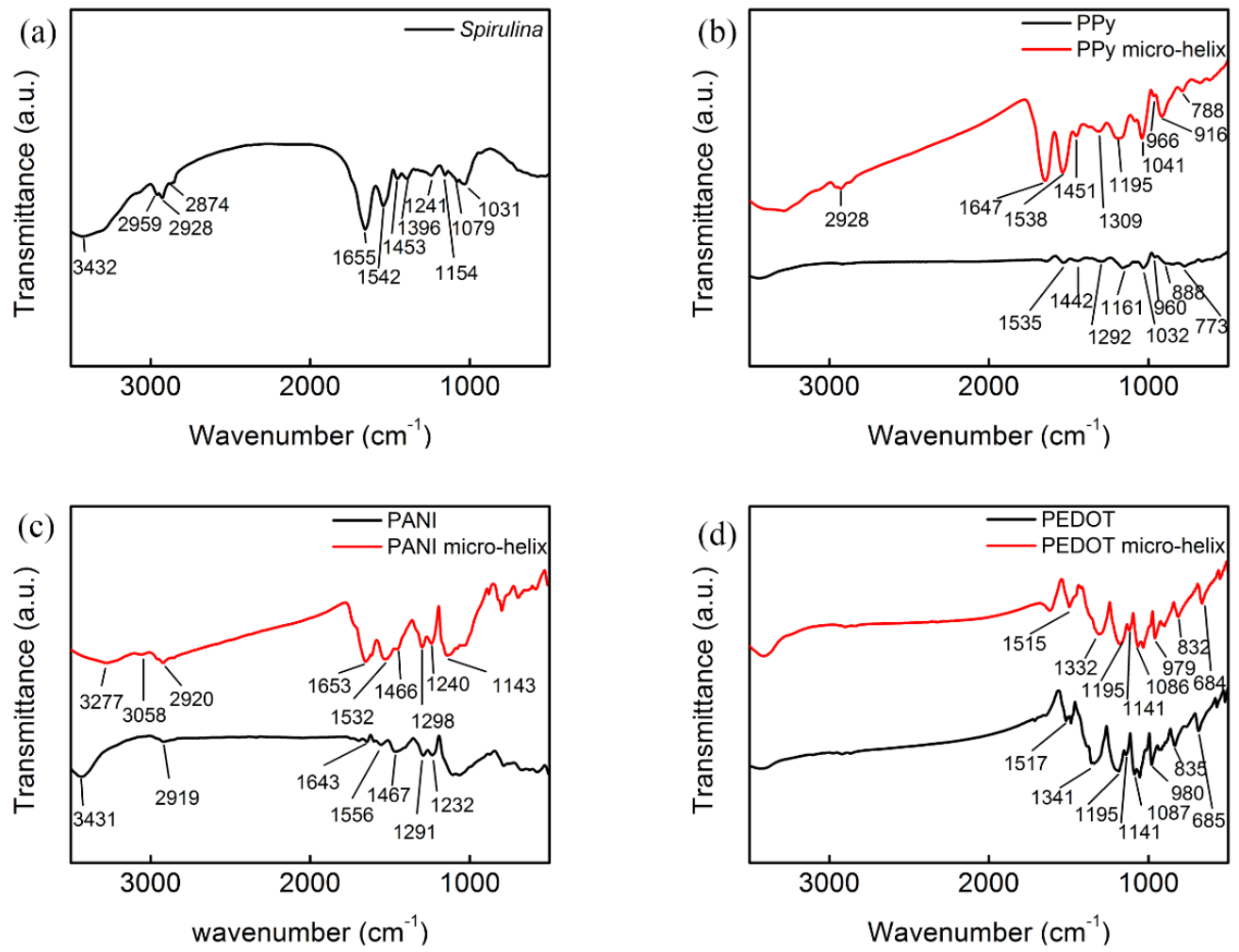

Figure 3. The Fourier transform infrared spectroscopy (FTIR) spectrum of Spirulina (a); PPy and the PPy micro-helix (b); PANI and the PANI micro-helix (c); and PEDOT and the PEDOT micro-helix (d).

FTIR spectra of free PPy and PPy micro-helix are shown in Figure 3b. A broad vibrational band between $3200-3500 \mathrm{~cm}^{-1}$ can be assigned to $\mathrm{N}-\mathrm{H}$ stretching vibrations [56]. The bands in the PPy micro-helix at about 2928 and $1647 \mathrm{~cm}^{-1}$ can be assigned to $s p^{3} \mathrm{C}-\mathrm{H}$ stretching and $\mathrm{N}-\mathrm{H}$ bending vibration, respectively [60]. Free PPy exhibits a distinct band at $1535 \mathrm{~cm}^{-1}$, which is attributed to C-C stretching vibrations in the pyrrole ring, while a small blue shift to $1538 \mathrm{~cm}^{-1}$ of this band is observed in the PPy micro-helix [61]. The bands at 1442 and $1451 \mathrm{~cm}^{-1}$ in the spectra of PPy and the PPy micro-helix correspond to $\mathrm{C}-\mathrm{N}$ stretching vibrations in the ring [61]. PPy and the PPy micro-helix have broad bands in the range of $1400-1250 \mathrm{~cm}^{-1}$ which can be assigned to $\mathrm{C}-\mathrm{H}$ or $\mathrm{C}-\mathrm{N}$ in-plane deformation modes with the maximum at 1292 and $1309 \mathrm{~cm}^{-1}$, respectively [62]. The bands between 1250 to $1100 \mathrm{~cm}^{-1}$ correspond to the breathing vibration of the pyrrole ring with the maximum at 1161 and $1195 \mathrm{~cm}^{-1}$ for PPy and the PPy micro-helix, respectively [62]. The bands of aromatic $\mathrm{C}-\mathrm{H}$ and $\mathrm{N}-\mathrm{H}$ in the plane deformation vibration situate in the region from 1130 to $1000 \mathrm{~cm}^{-1}$ for the PPy micro-helix and PPy [62,63]. The bands at 966 and $960 \mathrm{~cm}^{-1}$ can be assigned to C-C out-of-plane ring deformation vibrations of the PPy micro-helix and PPy, respectively [63]. The bands of C-H out-of-plane deformation vibrations have maximums at $916 \mathrm{~cm}^{-1}$ and $888 \mathrm{~cm}^{-1}$ for the PPy micro-helix and PPy, respectively. The peaks at 788 and $773 \mathrm{~cm}^{-1}$ correspond to the $\mathrm{C}-\mathrm{H}$ out-of-plane ring deformation of the PPy micro-helix and PPy, respectively [63].

FTIR spectra of free PANI and the PANI micro-helix are shown in Figure 3c. The peak at $3431 \mathrm{~cm}^{-1}$ for free PANI can be assigned to $\mathrm{N}-\mathrm{H}$ stretching vibration [64]. The bands at 3277 and $3058 \mathrm{~cm}^{-1}$ in the spectrum of the PANI micro-helix are due to hydrogen-bonded N-H stretching and aromatic C-H stretching, respectively [65]. Free PANI exhibits two distinct bands at 2919 and $1643 \mathrm{~cm}^{-1}$ which are attributed to the asymmetrically stretching vibration of $\mathrm{C}-\mathrm{H}$ and the $\mathrm{O}-\mathrm{H}$ bending of the absorbed water, respectively [66], while these bands show a slight blue-shift to 2920 and $1652 \mathrm{~cm}^{-1}$ in the spectrum of the PANI micro-helix. The absorption bands at 1556 and $1467 \mathrm{~cm}^{-1}$ in the spectrum of PANI can be assigned to the stretching vibrations of the quinoid $(\mathrm{N}=\mathrm{Q}=\mathrm{N})$ and 
benzoid (N-B-N) structure, respectively, while these bands have redshifts to 1532 and $1466 \mathrm{~cm}^{-1}$ in the PANI micro-helix, respectively. This result may suggest the existence of $\pi$ stacking interaction between PANI and Spirulina [67]. The band at $1298 \mathrm{~cm}^{-1}$ in the spectrum of the PANI micro-helix corresponds to $\pi$-electron delocalization which is caused by polymer protonation [63]. The band at $1291 \mathrm{~cm}^{-1}$ can be assigned to the bending vibrations of the $\mathrm{N}-\mathrm{H}$ mode of the polaron structure on the PANI micro-helix [68]. The band at $1240 \mathrm{~cm}^{-1}$ corresponds to the asymmetric $\mathrm{C}-\mathrm{N}^{+}$stretching vibration in the polaron structure on the PANI micro-helix and slightly shifts to $1232 \mathrm{~cm}^{-1}$ in the spectrum of PANI [63,69]. A specific band at $1143 \mathrm{~cm}^{-1}$ observed in the PANI micro-helix can be attributed to a vibration mode of the N-H structure which is absent in PANI [69].

FTIR spectra of free PEDOT and the PEDOT micro-helix are shown in Figure $3 \mathrm{~d}$. The bands at 1517 and $1341 \mathrm{~cm}^{-1}$ are attributed to the $C=C$ stretching modes or $C-C$ stretching of the quinoid structure in the thiophene ring, while the bands shift to 1515 and $1332 \mathrm{~cm}^{-1}$ in the spectrum of PEDOT micro-helix [70,71]. Peaks at 1195, 1141, and $1087 \mathrm{~cm}^{-1}$ that are due to $\mathrm{C}-\mathrm{O}-\mathrm{C}$ bond stretching in the ethylene dioxy group exist in both PEDOT and the PEDOT micro-helix [71]. The bands at 980, 835, and $685 \mathrm{~cm}^{-1}$ in the spectrum of PEDOT can be attributed to the deformation modes of the C-S bond in the thiophene ring which shift to 979,832 , and $684 \mathrm{~cm}^{-1}$ in the spectrum of the PEDOT micro-helix, respectively [70]. The bands around $3400 \mathrm{~cm}^{-1}$ in both PEDOT and the PEDOT micro-helix are attributed to the vibration of $\mathrm{H}_{2} \mathrm{O}$ and suggest water residue in the samples [72]. In addition, the band at $1640 \mathrm{~cm}^{-1}$ is ascribed to the $\mathrm{C}=\mathrm{C}$ stretching vibration which is strongly affected by the doping level of the conducting polymer [73] and suggests a higher doping level of the PEDOT micro-helix in comparison with that of PEDOT.

\subsection{Raman Spectroscopy Analysis}

In Figure $4 \mathrm{a}$, the band at $1577 \mathrm{~cm}^{-1}$ is assigned to the $\mathrm{C}=\mathrm{C}$ backbone stretching of PPy, and the band at $1380 \mathrm{~cm}^{-1}$ is attributed to the ring stretching mode for both PPy and the PPy micro-helix [74]. The band at $1240 \mathrm{~cm}^{-1}$ in the PPy micro-helix can be assigned to the anti-symmetrical C-H in-plane bending [75]. In both PPy and the PPy micro-helix, the peaks at $1050 \mathrm{~cm}^{-1}$ represent the symmetrical $\mathrm{C}-\mathrm{H}$ in-plane deformation and the peaks at $968 \mathrm{~cm}^{-1}$ are associated with the polaron structure [74,75]. The peak at $938 \mathrm{~cm}^{-1}$ in PPy and the peak at $935 \mathrm{~cm}^{-1}$ in the PPy micro-helix are attributed to ring deformation induced by dication (dipolaron) [76].

In Figure $4 \mathrm{~b}$, the bands at $1617 \mathrm{~cm}^{-1}$ in both PANI and the PANI micro-helix spectra are attributed to $C-C$ stretching [77]. The bands at $1588 \mathrm{~cm}^{-1}$ in PANI and at $1513 \mathrm{~cm}^{-1}$ in the PANI micro-helix may be associated with $C=C$ stretching in the quinonoid ring $[77,78]$, and the bands at $1562 \mathrm{~cm}^{-1}$ in PANI and at $1560 \mathrm{~cm}^{-1}$ in the PANI micro-helix can be attributed to the $C-C$ stretching of the intermediate structure between quinoid and semiquinoid [79]. The band at $1494 \mathrm{~cm}^{-1}$ in PANI represents benzenoid ring vibration ( $C=C$ stretching deformations) [80]. The bands at $1345 \mathrm{~cm}^{-1}$ in PANI and $1342 \mathrm{~cm}^{-1}$ in the PANI micro-helix can be attributed to $C-\mathrm{N}^{+}$stretching of radical cations [81]. The bands at $1187 \mathrm{~cm}^{-1}$ in the PANI micro-helix and at $1166 \mathrm{~cm}^{-1}$ in PANI can be assigned to C-H in-plane bending vibrations of bipolaronic forms and $\mathrm{C}-\mathrm{H}$ bending quinoid, respectively [81,82]. The bands at 814, 610, and $520 \mathrm{~cm}^{-1}$ in both the spectra may result from the $\mathrm{C}-\mathrm{N}-\mathrm{C}$ bending, ring deformation, and amine in-plane deformation, respectively $[82,83]$.

In Figure $4 \mathrm{c}$, the band of $\mathrm{C}=\mathrm{C}$ symmetrical stretching in the thiophene ring is at $1444 \mathrm{~cm}^{-1}$ in PEDOT and shifts to $1426 \mathrm{~cm}^{-1}$ in the PEDOT micro-helix [84,85]. The bands of asymmetrical $\mathrm{C}=\mathrm{C}$ stretching are at $1506 \mathrm{~cm}^{-1}$ for both PEDOT and the PEDOT micro-helix [86,87]. The peak at $1361 \mathrm{~cm}^{-1}$ that is related to $C-C$ stretching is only observed in the PEDOT micro-helix [87]. The peaks at $1265 \mathrm{~cm}^{-1}$ in the PEDOT micro-helix and $1274 \mathrm{~cm}^{-1}$ in PEDOT are assigned to the C-C inter-ring stretching mode [85]. The peaks of the C-C anti-symmetrical stretching mode can be seen at $983 \mathrm{~cm}^{-1}$ in the PEDOT micro-helix and $994 \mathrm{~cm}^{-1}$ in PEDOT [85]. 

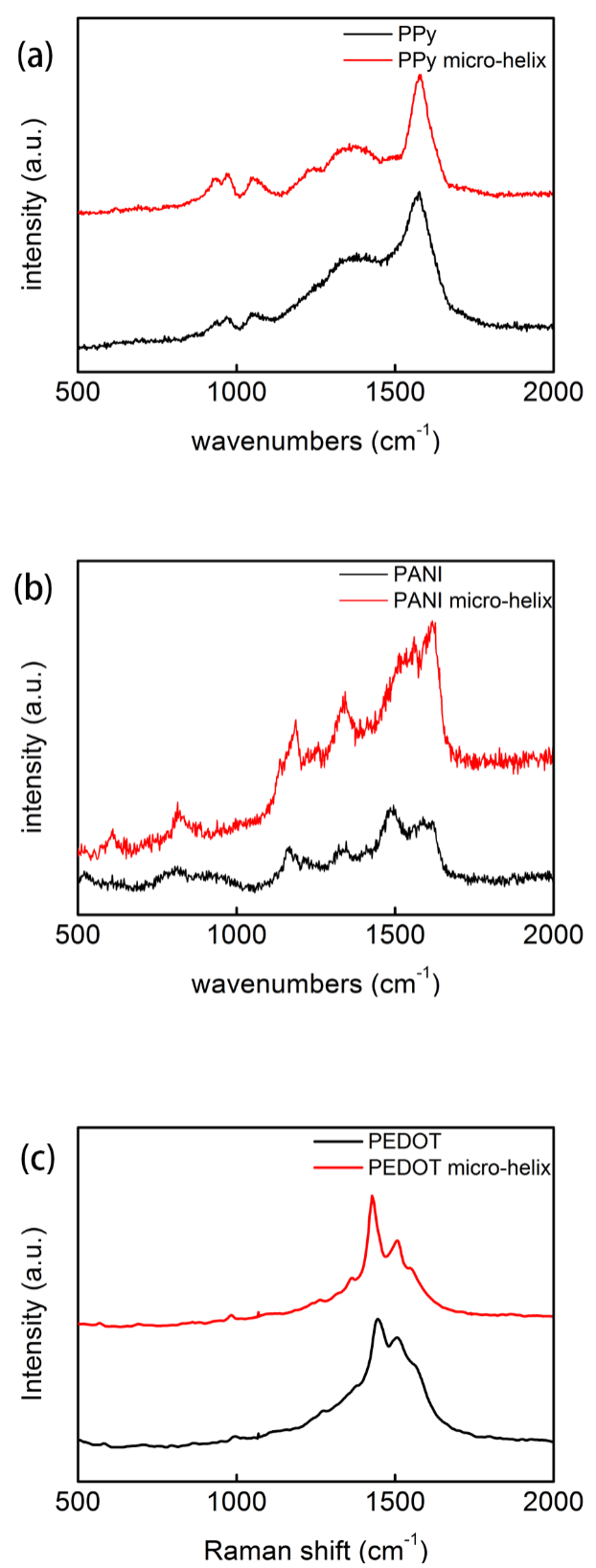

Figure 4. The Raman spectra of PPy and the PPy micro-helix (a); PANI and the PANI micro-helix (b); and PEDOT and the PEDOT micro-helix (c).

\subsection{X-ray Diffraction Analysis}

The crystal structures of PPy, the PPy micro-helix, PANI, the PANI micro-helix, PEDOT, and the PEDOT micro-helix were characterized by XRD analysis. Figure 5a shows the XRD pattern of PPy and the PPy micro-helix. The broad peaks in the region of $15-30^{\circ}$ for both PPy and the PPy micro-helix are mainly due to the scattering from PPy chains at the interplanar spacing and indicate a typical form of amorphous polymer [88]. The peaks that shift from $23.2^{\circ}$ in PPy to $21.6^{\circ}$ in the PPy micro-helix suggest the interaction between the Spirulina template surface and PPy coating [89]. In Figure 5b, the peaks at $2 \theta=14.8^{\circ}$ and $25.0^{\circ}$ in both PANI and the PANI micro-helix are caused by periodical perpendicularity and parallelism in the polymer chain, respectively. Additionally, the peak at $20.5^{\circ}$ can be attributed to the alternating distance of the polymer chain layers for both PANI and the PANI micro-helix $[90,91]$. The broadened peaks at $2 \theta=14.8^{\circ}$ and $25.0^{\circ}$ in the PANI micro-helix can be 
attributed to the intermolecular interaction between PANI and the Spirulina surface [92]. In Figure 5c, both PEDOT and the PEDOT helix have wide diffraction peaks in the region of $2 \theta=22-28^{\circ}$, which suggest their amorphous forms $[93,94]$. The peak at $2 \theta=25.4^{\circ}$ in PEDOT shifted to $2 \theta=25.6^{\circ}$ in the PEDOT helix, which suggests the increase of the doping level $[95,96]$.
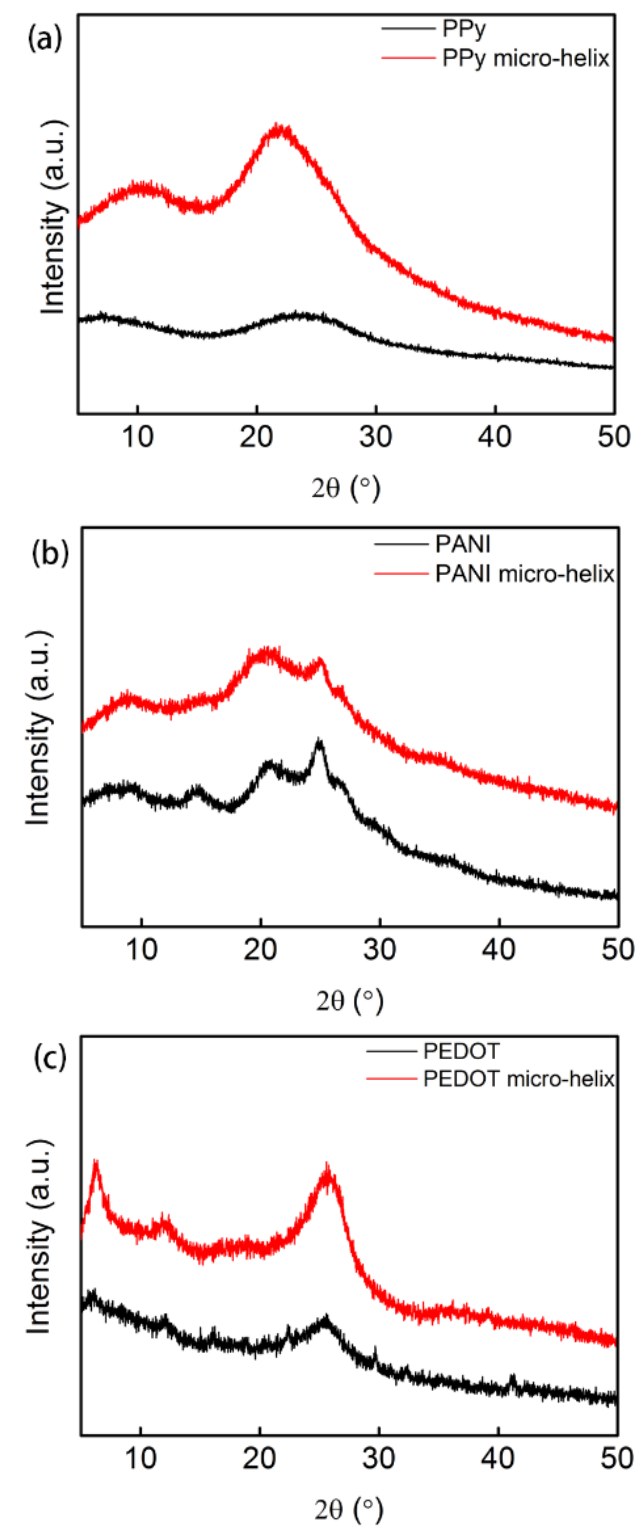

Figure 5. The X-ray diffraction (XRD) pattern of PPy and the PPy micro-helix (a); PANI and the PANI micro-helix (b); and PEDOT and the PEDOT micro-helix (c).

\subsection{Electrical and Electrochemical Properties}

Four-point probes were used to determine the sheet resistance of the conducting polymer micro-helices without any extra disposition. The sheet resistances of the PPy micro-helix, the PANI micro-helix, and the PEDOT micro-helix are measured as $10.2 \pm 0.60,17.7 \pm 2.22$, and $42.2 \pm 3.15 \Omega / \mathrm{sq}$, respectively. The sheet resistance of the PPy micro-helix is close to that of the reported PPy/MWCNT/cotton (6.0 $\pm 0.4 \Omega$ /sq) [97]. The sheet resistance of the PANI micro-helix is at the same level as that of the reported pristine PANI (about $5 \Omega / \mathrm{sq})[98,99]$. The sheet resistance of the PEDOT micro-helix is much better than that of the PEDOT/PET films (190 $\Omega /$ sq) [100]. 
For a single electrode, its specific capacitance, $C_{\mathrm{S}}(\mathrm{F} / \mathrm{g})$ can be calculated from $\mathrm{CV}$ curves:

$$
C_{\mathrm{s}}=\frac{\int I d V}{v m \Delta U}
$$

where $\Delta U$ is the potential window, $v$ is the scan rate, $m$ is the mass of the active material electrode, $I$ is the current, and $V$ is the voltage.

In Figure 6, the CV curves of the PPy micro-helix, the PANI micro-helix, and the PEDOT micro-helix with a series of scan rates exhibit a double-layer capacitance characteristic. In Figure 6a, the highest specific capacitance of the PPy micro-helix was found to be $234 \mathrm{~F} / \mathrm{g}$, which is almost the same as those of the reported PPy-coated cotton $(268 \mathrm{~F} / \mathrm{g})$ and PPy-coated viscose rayon $(244 \mathrm{~F} / \mathrm{g})$, and higher than those of the reported PMAS/PPy-coated Actitex carbon fiber $(152.0 \mathrm{~F} / \mathrm{g})$ and PPy-coated acrylonitrile butadiene rubber $(125.8 \mathrm{~F} / \mathrm{g}$ ) with the same scan rate [101-103]. In Figure 6b, the highest specific capacitance of the PANI micro-helix was found to be $238 \mathrm{~F} / \mathrm{g}$, which is slightly higher than that of the reported PMAS/PANI-coated Actitex carbon fiber $(212 \mathrm{~F} / \mathrm{g})[102,104]$. In Figure $6 \mathrm{c}$, with the scan rate of $10 \mathrm{mV} / \mathrm{s}$, the PEDOT micro-helix showed the highest specific capacitance of $106.4 \mathrm{~F} / \mathrm{g}$, which is higher than that of the reported CNTs/PEDOT composite (85/15, $w / w)(70 \mathrm{~F} / \mathrm{g})$ [105]. EIS measurements were also carried out to study the characteristics of charge transfer in conducting polymers. An electrical equivalent circuit model for the conducting polymer micro-helix which is composed of electrolyte resistance $\left(R_{\mathrm{s}}\right)$, double-layer capacitance $\left(C_{\mathrm{d}}\right)$, charge transfer resistance $\left(R_{\mathrm{ct}}\right)$, and Warburg impedance $\left(Z_{\mathrm{W}}\right)$ was introduced to fit the EIS result, as shown in Figure 7 inset $[97,106]$. In the high-frequency region, the well-defined semicircles which represent charge transfer-dominated regimes and whose diameters represent the charge transfer resistance $\left(R_{\mathrm{ct}}\right)$ are observed for all the micro-helices. The $R_{\mathrm{ct}}$ values of the PPy micro-helix, the PANI micro-helix, and the PEDOT micro-helix-modified electrodes are calculated as $1.666,1.68$, and $1.565 \Omega$, respectively, which is in the same level as those of the reported PPy/graphene electrode film $(0.15-1.73 \Omega)$ [107] and better than those of the reported PANI/ $\mathrm{MnWO}_{4}$ composite $(22 \Omega)$ [108] and PEDOT-coated Au microelectrode arrays $(749 \Omega)$ [109]. This result suggests that the micro-sized Spirulina bio-template can effectively enlarge the specific surface of the conducting polymer, which facilitates counterion exchange on the electrode/electrolyte interface. The $R_{s}$ value of the PANI micro-helix and the PEDOT micro-helix are extracted as 3.737 and $4.108 \Omega$, respectively, which is much lower than that $(8.201 \Omega)$ of the PPy micro-helix, suggesting that the PANI micro-helix and the PEDOT micro-helix have low internal resistances for ion transfer in $\mathrm{Na}_{2} \mathrm{SO}_{4}$ aqueous solution.

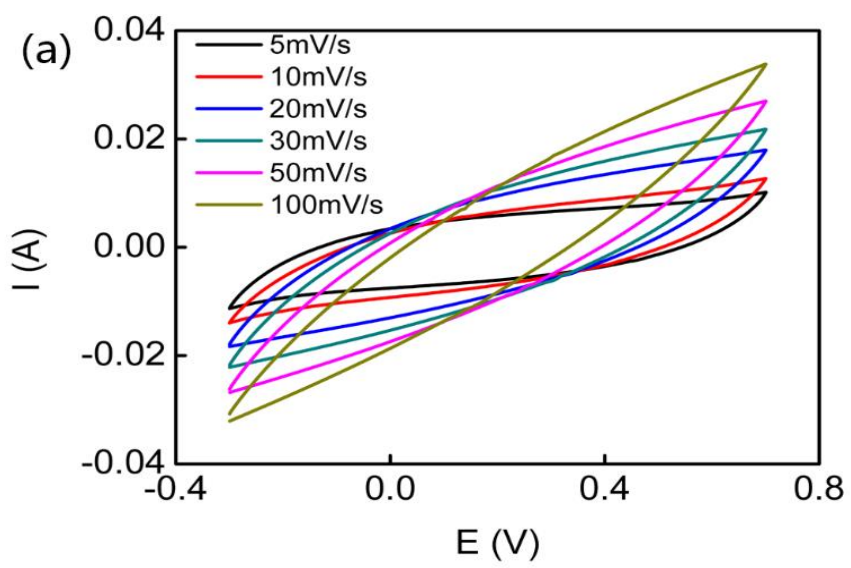

Figure 6. Cont. 

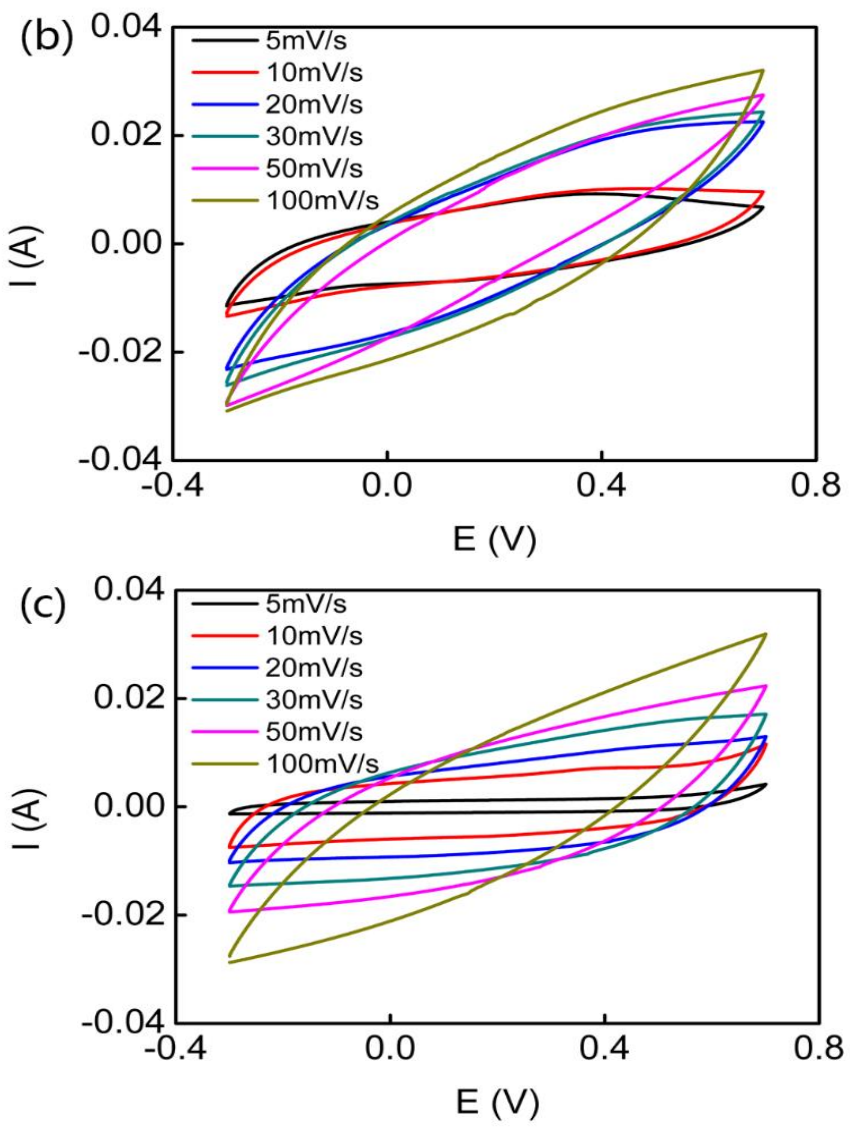

Figure 6. The cyclic voltammograms of the PPy micro-helix (a); the PANI micro-helix (b); and the PEDOT micro-helix (c) with different scan rates from $5 \mathrm{mV} / \mathrm{s}$ to $100 \mathrm{mV} / \mathrm{s}$.

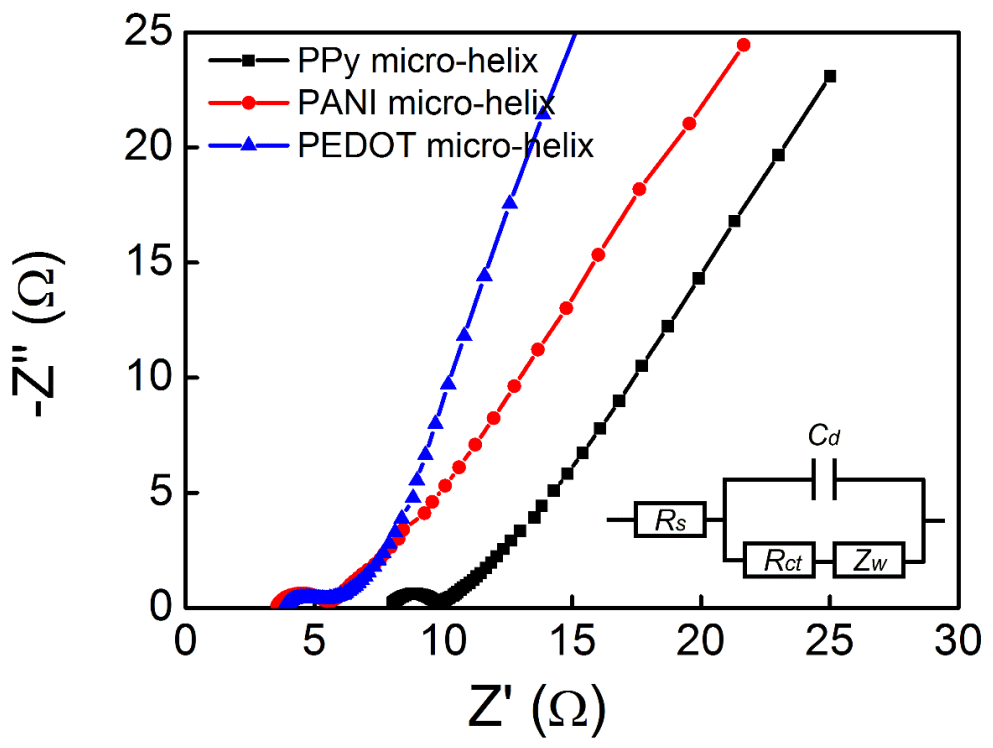

Figure 7. The Nyquist plots for the PPy micro-helix, the PANI micro-helix, and the PEDOT micro-helix in the frequency range of $10^{5} \mathrm{~Hz}$ to $0.01 \mathrm{~Hz}$ at an open circuit potential with an alternating current (AC) perturbation of $10 \mathrm{mV}$; inset: the electrical equivalent circuit for PPy, PANI, and the PEDOT micro-helix. 


\section{Conclusions}

In this study, we proposed a new strategy to fabricate conducting polymers in micro-helical form by using naturally-occurring Spirulina as a helical bio-template. In comparison with the conventional techniques for manufacturing micro-helices, Spirulina-templated conducting polymer micro-helices can be easily mass produced with an extremely low cost. The PPy micro-helix, the PANI micro-helix, and the PEDOT micro-helix were successfully synthesized in fine helical form. The strong interactions between the conducting polymers and the surface groups of Spirulina can be inferred from the multiple molecular structure analysis. The sheet resistances of the PPy micro-helix, the PANI micro-helix, and the PEDOT micro-helix are measured as $10.2 \pm 0.60,17.7 \pm 2.22$, and $42.2 \pm 3.15 \Omega / \mathrm{sq}$, and the optimized specific capacitances of the PPy micro-helix, the PANI micro-helix, and the PEDOT micro-helix were found to be 234,238 , and $106.4 \mathrm{~F} / \mathrm{g}$ with scan rates of 5, 5, and $10 \mathrm{mV} / \mathrm{s}$, respectively, which are comparable to other conducting polymer-coated micro-fiber materials. Moreover, this approach can be applied to produce other kinds of conducting polymer micro-helices and to further combine with functional nanomaterials with customized physical and chemical properties for making biomedical and microelectronic devices.

Author Contributions: W.C. and J.Z. conceived and designed the experiments; X.-Y.H., J.O., G.-C.L., M.-J.G., and L.-B.S. performed the experiments; X.-Y.H. and J.O. analyzed the data; and X.-Y.H. and W.C. wrote the paper.

Funding: This research was funded by the National Key Research and Development Program of China (no. 2017YFA0700402), the Applied Basic Research Program of Wuhan City (no. 2016060101010048), and the Natural Science Foundation of Hubei Province (no. 2017CFB732).

Acknowledgments: The authors would like to acknowledge Hubei Boffin Technology Co. Ltd. for the support on this research and the Analytical and Testing Center (HUST) for the help of measurement.

Conflicts of Interest: The authors declare no conflict of interest.

\section{References}

1. Xu, P.; Xie, R.; Liu, Y.; Luo, G.; Ding, M.; Liang, Q. Bioinspired microfibers with embedded perfusable helical channels. Adv. Mater. 2017, 29, 1701664. [CrossRef] [PubMed]

2. Huang, H.-W.; Sakar, M.S.; Petruska, A.J.; Pane, S.; Nelson, B.J. Soft micromachines with programmable motility and morphology. Nat. Commun. 2016, 7, 12263. [CrossRef] [PubMed]

3. Tottori, S.; Zhang, L.; Qiu, F.; Krawczyk, K.K.; Franco-Obregon, A.; Nelson, B.J. Magnetic helical micromachines: Fabrication, controlled swimming, and cargo transport. Adv. Mater. 2012, 24, 811-816. [CrossRef] [PubMed]

4. Yan, X.; Zhou, Q.; Yu, J.; Xu, T.; Deng, Y.; Tang, T.; Feng, Q.; Bian, L.; Zhang, Y.; Ferreira, A.; et al. Magnetite nanostructured porous hollow helical microswimmers for targeted delivery. Adv. Funct. Mater. 2015, 25, 5333-5342. [CrossRef]

5. Sengupta, S.; Ibele, M.E.; Sen, A. Fantastic voyage: Designing self-powered nanorobots. Angew. Chem. Int. Ed. 2012, 51, 8434-8445. [CrossRef] [PubMed]

6. Peyer, K.E.; Zhang, L.; Nelson, B.J. Bio-inspired magnetic swimming microrobots for biomedical applications. Nanoscale 2013, 5, 1259-1272. [CrossRef] [PubMed]

7. Li, J.; Sattayasamitsathit, S.; Dong, R.; Gao, W.; Tam, R.; Feng, X.; Ai, S.; Wang, J. Template electrosynthesis of tailored-made helical nanoswimmers. Nanoscale 2014, 6, 9415-9420. [CrossRef] [PubMed]

8. Yan, X.; Zhou, Q.; Vincent, M.; Deng, Y.; Yu, J.; Xu, J.; Xu, T.; Tang, T.; Bian, L.; Wang, Y.X.J. Multifunctional biohybrid magnetite microrobots for imaging-guided therapy. Sci. Robot. 2017, 2, 1155. [CrossRef]

9. Gansel, J.K.; Thiel, M.; Rill, M.S.; Decker, M.; Bade, K.; Saile, V.; von Freymann, G.; Linden, S.; Wegener, M. Gold helix photonic metamaterial as broadband circular polarizer. Science 2009, 325, 1513-1515. [CrossRef] [PubMed]

10. Li, W.; Huang, G.; Wang, J.; Yu, Y.; Wu, X.; Cui, X.; Mei, Y. Superelastic metal microsprings as fluidic sensors and actuators. Lab Chip 2012, 12, 2322-2328. [CrossRef] [PubMed]

11. Kesapragada, S.V.; Victor, P.; Nalamasu, O.; Gall, D. Nanospring pressure sensors grown by glancing angle doposition. Nano Lett. 2006, 6, 854-857. [CrossRef] [PubMed] 
12. Yang, D.; Fonseca, L.F. Wet-chemical approaches to porous nanowires with linear, spiral, and meshy topologies. Nano Lett. 2013, 13, 5642-5646. [CrossRef] [PubMed]

13. Singh, J.P.; Liu, D.L.; Ye, D.X.; Picu, R.C.; Lu, T.M.; Wang, G.C. Metal-coated si springs: Nanoelectromechanical actuators. Appl. Phys. Lett. 2004, 84, 3657-3659. [CrossRef]

14. Gong, J.; Lin, H.; Dunlop, J.W.C.; Yuan, J. Hierarchically arranged helical fiber actuators derived from commercial cloth. Adv. Mater. 2017, 29, 1605103. [CrossRef] [PubMed]

15. Gu, X.; Fan, Q.; Yang, F.; Cai, L.; Zhang, N.; Zhou, W.; Zhou, W.; Xie, S. Hydro-actuation of hybrid carbon nanotube yarn muscles. Nanoscale 2016, 8, 17881-17886. [CrossRef] [PubMed]

16. Kim, S.H.; Kwon, C.H.; Park, K.; Mun, T.J.; Lepro, X.; Baughman, R.H.; Spinks, G.M.; Kim, S.J. Bio-inspired, moisture-powered hybrid carbon nanotube yarn muscles. Sci. Rep. 2016, 6, 23016. [CrossRef] [PubMed]

17. Yang, J.; Li, B.; Zhang, Q.; Yim, W.-1.; Chen, L. Catalytic oxygen activation on helical gold nanowires. J. Phys. Chem. C 2012, 116, 11189-11194. [CrossRef]

18. Fan, Z.; Govorov, A.O. Chiral nanocrystals: Plasmonic spectra and circular dichroism. Nano Lett. 2012, 12, 3283-3289. [CrossRef] [PubMed]

19. Droulias, S.; Yannopapas, V. Broad-band giant circular dichroism in metamaterials of twisted chains of metallic nanoparticles. J. Phys. Chem. C 2013, 117, 1130-1135. [CrossRef]

20. Lu, Z.; Zhao, M.; Xie, P.; Wu, L.; Yu, Y.; Zhang, P.; Yang, Z. Reflection properties of metallic helical metamaterials. J. Lightwave Technol. 2012, 30, 3050-3054. [CrossRef]

21. Kessick, R.; Tepper, G. Microscale polymeric helical structures produced by electrospinning. Appl. Phys. Lett. 2004, 84, 4807-4809. [CrossRef]

22. Kaschke, J.; Wegener, M. Gold triple-helix mid-infrared metamaterial by sted-inspired laser lithography. Opt. Lett. 2015, 40, 3986-3989. [CrossRef] [PubMed]

23. Shang, Y.; Wang, C.; He, X.; Li, J.; Peng, Q.; Shi, E.; Wang, R.; Du, S.; Cao, A.; Li, Y. Self-stretchable, helical carbon nanotube yarn supercapacitors with stable performance under extreme deformation conditions. Nano Energy 2015, 12, 401-409. [CrossRef]

24. Yu, Y.; Fu, F.; Shang, L.; Cheng, Y.; Gu, Z.; Zhao, Y. Bioinspired helical microfibers from microfluidics. Adv. Mater. 2017, 29, 1605765. [CrossRef] [PubMed]

25. Mark, A.G.; Gibbs, J.G.; Lee, T.-C.; Fischer, P. Hybrid nanocolloids with programmed three-dimensional shape and material composition. Nat. Mater. 2013, 12, 802-807. [CrossRef] [PubMed]

26. Gao, W.; Peng, X.; Pei, A.; Kane, C.R.; Tam, R.; Hennessy, C.; Wang, J. Bioinspired helical microswimmers based on vascular plants. Nano Lett. 2014, 14, 305-310. [CrossRef] [PubMed]

27. Zhou, H.; Fan, T.; Zhang, D. Biotemplated materials for sustainable energy and environment: Current status and challenges. ChemSusChem 2011, 4, 1344-1387. [CrossRef] [PubMed]

28. Kamata, K.; Suzuki, S.; Ohtsuka, M.; Nakagawa, M.; Iyoda, T.; Yamada, A. Fabrication of left-handed metal microcoil from spiral vessel of vascular plant. Adv. Mater. 2011, 23, 5509-5513. [CrossRef] [PubMed]

29. Zafaralla, M.T.; Barril, C.R.; Vidal, L.R. Protein from spirulina. NSTA Technol. J. 1985, 10, 18-26.

30. Zhang, D.; Zhang, W.; Cai, J. Magnetization of microorganism cells by thermal decomposition method. Sci. China-Technol. Sci. 2011, 54, 1275-1280. [CrossRef]

31. Courchesne, N.-M.D.; Steiner, S.A., III; Cantu, V.J.; Hammond, P.T.; Belcher, A.M. Biotemplated silica and silicon materials as building blocks for micro- to nanostructures. Chem. Mater. 2015, 27, 5361-5370. [CrossRef]

32. Kamata, K.; Piao, Z.; Suzuki, S.; Fujimori, T.; Tajiri, W.; Nagai, K.; Iyoda, T.; Yamada, A.; Hayakawa, T.; Ishiwara, M.; et al. Spirulina-templated metal microcoils with controlled helical structures for thz electromagnetic responses. Sci. Rep. 2014, 4, 4919. [CrossRef] [PubMed]

33. Liu, J.; Zhang, X.; Li, S.; Yu, M. Preparation and characterization of metallic Cu spiral based on spirulina bioscaffold. Mater. Lett. 2012, 77, 51-53. [CrossRef]

34. Zhang, X.; Yu, M.; Liu, J.; Li, S. Bioinspired synthesis of a hollow metallic microspiral based on a spirulina bioscaffold. Langmuir 2012, 28, 3690-3694. [CrossRef] [PubMed]

35. Lan, M.; Cai, J.; Yuan, L.; Xu, Y.; Zhang, D. Fabrication and electromagnetic properties of soft-core functional particles by way of electroless Ni-Fe-P alloy plating on helical microorganism cells. Surf. Coat. Tech. 2013, 216, 152-157. [CrossRef]

36. Cai, J.; Lan, M.; Zhang, D.; Zhang, W. Electrical resistivity and dielectric properties of helical microorganism cells coated with silver by electroless plating. Appl. Surf. Sci. 2012, 258, 8769-8774. [CrossRef] 
37. Olsson, H.; Nystrom, G.; Stromme, M.; Sjodin, M.; Nyholm, L. Cycling stability and self-protective properties of a paper-based polypyrrole energy storage device. Electrochem. Commun. 2011, 13, 869-871. [CrossRef]

38. Das, C.; Krishnamoorthy, K. Flexible microsupercapacitors using silk and cotton substrates. ACS Appl. Mater. Interfaces 2016, 8, 29504-29510. [CrossRef] [PubMed]

39. Kizling, M.; Stolarczyk, K.; Kiat, J.S.S.; Tammela, P.; Wang, Z.; Nyholm, L.; Bilewicz, R. Pseudocapacitive polypyrrole-nanocellulose composite for sugar-air enzymatic fuel cells. Electrochem. Commun. 2015, 50, 55-59. [CrossRef]

40. Spinks, G.M.; Mottaghitalab, V.; Bahrami-Saniani, M.; Whitten, P.G.; Wallace, G.G. Carbon-nanotube-reinforced polyaniline fibers for high-strength artificial muscles. Adv. Mater. 2006, 18, 637-640. [CrossRef]

41. Hardy, J.G.; Lee, J.Y.; Schmidt, C.E. Biomimetic conducting polymer-based tissue scaffolds. Curr. Opin. Biotechnol. 2013, 24, 847-854. [CrossRef] [PubMed]

42. Simon, D.T.; Kurup, S.; Larsson, K.C.; Hori, R.; Tybrandt, K.; Goiny, M.; Jager, E.H.; Berggren, M.; Canlon, B.; Richter-Dahlfors, A. Organic electronics for precise delivery of neurotransmitters to modulate mammalian sensory function. Nat. Mater. 2009, 8, 742-746. [CrossRef] [PubMed]

43. Xu, Z.; Gao, C. Graphene in macroscopic order: Liquid crystals and wet-spun fibers. Accounts Chem. Res. 2014, 47, 1267-1276. [CrossRef] [PubMed]

44. Tian, X.; Wang, Q.; Chen, X.; Yang, W.; Wu, Z.; Xu, X.; Jiang, M.; Zhou, Z. Enhanced performance of core-shell structured polyaniline at helical carbon nanotube hybrids for ammonia gas sensor. Appl. Phys. Lett. 2014, 105, 203109. [CrossRef]

45. Backlund, F.G.; Elfwing, A.; Musumeci, C.; Ajjan, F.; Babenko, V.; Dzwolak, W.; Solin, N.; Inganas, O. Conducting microhelices from self-assembly of protein fibrils. Soft Matter 2017, 13, 4412-4417. [CrossRef] [PubMed]

46. Sarrazin, J.C.; Mascaro, S.A. Sequential growth and monitoring of a polypyrrole actuator system. In Proceedings of the Electroactive Polymer Actuators and Devices, San Diego, CA, USA, 9-13 March 2014; Volume 9056, p. 90563.

47. Tadesse, Y.; Grange, R.W.; Priya, S. Synthesis and cyclic force characterization of helical polypyrrole actuators for artificial facial muscles. Smart Mater. Struct. 2009, 18, 085008. [CrossRef]

48. Cheng, M.Y.; Tsao, C.M.; Lai, Y.Z.; Yang, Y.J. The development of a highly twistable tactile sensing array with stretchable helical electrodes. Sens. Actuator A Phys. 2011, 166, 226-233. [CrossRef]

49. Chen, W.; Li, C.M.; Chen, P.; Sun, C.Q. Electrosynthesis and characterization of polypyrrole/au nanocomposite. Electrochim. Acta 2007, 52, 2845-2849. [CrossRef]

50. Beveridge, T.J.; Graham, L.L. Surface layers of bacteria. Microbiol. Rev. 1991, 55, 684-705. [PubMed]

51. Weckesser, J.; Jügrens, U.J. Cell walls and external layers. In Method. Enzymol.; Academic Press: Cambridge, MA, USA, 1988; Volume 167, pp. 173-188.

52. Hoiczyk, E.; Hansel, A. Cyanobacterial cell walls: News from an unusual prokaryotic envelope. J. Bacteriol. 2000, 182, 1191-1199. [CrossRef] [PubMed]

53. Johnston, J.H.; Moraes, J.; Borrmann, T. Conducting polymers on paper fibres. Synth. Met. 2005, 153, 65-68. [CrossRef]

54. Li, Q.; Zhang, C.; Ye, Y. Synthesis and characterization of polyaniline microbelt via cotton template. J. Thermoplast. Compos. Mater. 2011, 24, 389-398. [CrossRef]

55. Gagrai, M.K.; Das, C.; Golder, A.K. Non-ideal metal binding model for Cr(iii) sorption using Spirulina platensis biomass: Experimental and theoretical approach. Can. J. Chem. Eng. 2013, 91, 1904-1912. [CrossRef]

56. Koduru, H.K.; Marino, L.; Vallivedu, J.; Choi, C.-J.; Scaramuzza, N. Microstructural, wetting, and dielectric properties of plasma polymerized polypyrrole thin films. J. Appl. Polym. Sci. 2016, 133, 43982. [CrossRef]

57. Liu, H.J.; Xu, C.H.; Zhou, Q.; Wang, F.; Li, W.M.; Ha, Y.M.; Sun, S.Q. Analysis and identification of irradiated spirulina powder by a three-step infrared macro-fingerprint spectroscopy. Radiat. Phys. Chem. 2013, 85, 210-217. [CrossRef]

58. Park, D.; Yun, Y.S.; Park, J.M. Studies on hexavalent chromium biosorption by chemically-treated biomass of ecklonia sp. Chemosphere 2005, 60, 1356-1364. [CrossRef] [PubMed]

59. Arief, V.O.; Trilestari, K.; Sunarso, J.; Indraswati, N.; Ismadji, S. Recent progress on biosorption of heavy metals from liquids using low cost biosorbents: Characterization, biosorption parameters and mechanism studies. Clean-Soil Air Water 2008, 36, 937-962. [CrossRef] 
60. Hebeish, A.; Farag, S.; Sharaf, S.; Shaheen, T.I. Advancement in conductive cotton fabrics through in situ polymerization of polypyrrole-nanocellulose composites. Carbohydr. Polym. 2016, 151, 96-102. [CrossRef] [PubMed]

61. Muller, D.; Rambo, C.R.; Porto, L.M.; Schreiner, W.H.; Barra, G.M.O. Structure and properties of polypyrrole/bacterial cellulose nanocomposites. Carbohydr. Polym. 2013, 94, 655-662. [CrossRef] [PubMed]

62. Omastova, M.; Trchova, M.; Kovarova, J.; Stejskal, J. Synthesis and structural study of polypyrroles prepared in the presence of surfactants. Synth. Met. 2003, 138, 447-455. [CrossRef]

63. Blinova, N.V.; Stejskal, J.; Trchova, M.; Prokes, J.; Omastova, M. Polyaniline and polypyrrole: A comparative study of the preparation. Eur. Polym. J. 2007, 43, 2331-2341. [CrossRef]

64. Kumar, S.; Jain, S. One-step synthesis of superparamagnetic $\mathrm{Fe}_{3} \mathrm{O}_{4} @ P A N I$ nanocomposites. J. Chem. 2014, 2014, 1-6. [CrossRef]

65. Trchova, M.; Stejskal, J. Polyaniline: The infrared spectroscopy of conducting polymer nanotubes (iupac technical report). Pure Appl. Chem. 2011, 83, 1803-1817. [CrossRef]

66. Muller, D.; Mandelli, J.S.; Marins, J.A.; Soares, B.G.; Porto, L.M.; Rambo, C.R.; Barra, G.M.O. Electrically conducting nanocomposites: Preparation and properties of polyaniline (PAni)-coated bacterial cellulose nanofibers (BC). Cellulose 2012, 19, 1645-1654. [CrossRef]

67. Chal, P.; Shit, A.; Nandi, A.K. Dye-sensitized solar cell from a new organic n-type semiconductor/polyaniline composite: Insight from impedance spectroscopy. J. Mater. Chem. C 2016, 4, 272-285. [CrossRef]

68. Saini, P.; Choudhary, V.; Singh, B.P.; Mathur, R.B.; Dhawan, S.K. Polyaniline-mwcnt nanocomposites for microwave absorption and emi shielding. Mater. Chem. Phys. 2009, 113, 919-926. [CrossRef]

69. Trchova, M.; Sedenkova, I.; Stejskal, J. In-situ polymerized polyaniline films 6. Ftir spectroscopic study of aniline polymerization. Synth. Met. 2005, 154, 1-4. [CrossRef]

70. Ohlan, A.; Singh, K.; Chandra, A.; Dhawan, S.K. Microwave absorption behavior of core-shell structured poly(3,4-ethylenedioxy thiophene)-barium ferrite nanocomposites. ACS Appl. Mater. Interfaces 2010, 2, 927-933. [CrossRef] [PubMed]

71. Reddy, K.R.; Park, W.; Sin, B.C.; Noh, J.; Lee, Y. Synthesis of electrically conductive and superparamagnetic monodispersed iron oxide-conjugated polymer composite nanoparticles by in situ chemical oxidative polymerization. J. Colloid Interface Sci. 2009, 335, 34-39. [CrossRef] [PubMed]

72. Zhang, X.; Liu, J.; Xu, B.; Su, Y.; Luo, Y. Ultralight conducting polymer/carbon nanotube composite aerogels. Carbon 2011, 49, 1884-1893. [CrossRef]

73. Shin, S.; Jang, J. Thiol containing polymer encapsulated magnetic nanoparticles as reusable and efficiently separable adsorbent for heavy metal ions. Chem. Commun. 2007, 4230-4232. [CrossRef]

74. Han, G.; Yuan, J.; Shi, G.; Wei, F. Electrodeposition of polypyrrole/multiwalled carbon nanotube composite films. Thin Solid Films 2005, 474, 64-69. [CrossRef]

75. Duchet, J.; Legras, R.; Demoustier-Champagne, S. Chemical synthesis of polypyrrole: Structure-properties relationship. Synth. Met. 1998, 98, 113-122. [CrossRef]

76. Chen, F.e.; Shi, G.; Fu, M.; Qu, L.; Hong, X. Raman spectroscopic evidence of thickness dependence of the doping level of electrochemically deposited polypyrrole film. Synth. Met. 2003, 132, 125-132. [CrossRef]

77. Cong, H.-P.; Ren, X.-C.; Wang, P.; Yu, S.-H. Flexible graphene-polyaniline composite paper for high-performance supercapacitor. Energy Environ. Sci. 2013, 6, 1185-1191. [CrossRef]

78. Yan, X.; Chen, J.; Yang, J.; Xue, Q.; Miele, P. Fabrication of free-standing, electrochemically active, and biocompatible graphene oxide-polyaniline and graphene-polyaniline hybrid papers. ACS Appl. Mater. Interfaces 2010, 2, 2521-2529. [CrossRef] [PubMed]

79. Lindfors, T.; Ivaska, A. Raman based ph measurements with polyaniline. J. Electroanal. Chem. 2005, 580, 320-329. [CrossRef]

80. Sun, Y.; Shao, D.; Chen, C.; Yang, S.; Wang, X. Highly efficient enrichment of radionuclides on graphene oxide-supported polyaniline. Environ. Sci. Technol. 2013, 47, 9904-9910. [CrossRef] [PubMed]

81. Bernard, M.C.; Hugot-Le Goff, A. Quantitative characterization of polyaniline films using raman spectroscopy: I: Polaron lattice and bipolaron. Electrochim. Acta 2006, 52, 595-603. [CrossRef]

82. Jain, M.; Annapoorni, S. Raman study of polyaniline nanofibers prepared by interfacial polymerization. Synth. Met. 2010, 160, 1727-1732. [CrossRef] 
83. Bernard, M.C.; Hugot-Le Goff, A.; Arkoub, H.; Saïdani, B. Characterization of substituted polyaniline films using raman spectroscopy: Iii. Study of a methoxylated polymer: Poma. Electrochim. Acta 2007, 52, 5030-5038. [CrossRef]

84. Pang, F.-F.; Li, S.; Sun, W.-Q.; Han, G.-Z. Reversible conductivity modulation of pedot:Pss based on ph. Mater. Chem. Phys. 2017, 186, 246-250. [CrossRef]

85. Wang, X.J.; Wong, K.Y. Effects of a base coating used for electropolymerization of poly(3,4-ethylenedioxythiophene) on indium tin oxide electrode. Thin Solid Films 2006, 515, 1573-1578. [CrossRef]

86. Back, J.-W.; Lee, S.; Hwang, C.-R.; Chi, C.-S.; Kim, J.-Y. Fabrication of conducting pedot nanotubes using vapor deposition polymerization. Macromol. Res. 2011, 19, 33-37. [CrossRef]

87. Garcia-Barbera, A.; Culebras, M.; Roig-Sanchez, S.; Gomez, C.M.; Cantarero, A. Three dimensional pedot nanowires network. Synth. Met. 2016, 220, 208-212. [CrossRef]

88. He, C.; Yang, C.H.; Li, Y.F. Chemical synthesis of coral-like nanowires and nanowire networks of conducting polypyrrole. Synth. Met. 2003, 139, 539-545. [CrossRef]

89. Hazarika, J.; Kumar, A. Swift heavy ion irradiation effects on structural, optical properties and ac conductivity of polypyrrole nanofibers. Radiat. Eff. Defects Solids 2016, 171, 978-998. [CrossRef]

90. Huang, H.; Feng, X.; Zhu, J.-J. Synthesis, characterization and application in electrocatalysis of polyaniline/au composite nanotubes. Nanotechnology 2008, 19, 145607. [CrossRef] [PubMed]

91. Zhang, L.; Waterhouse, G.I.N.; Zhang, L. Coaxially aligned polyaniline nanofibers doped with 3-thiopheneacetic acid through interfacial polymerization. J. Nanomater. 2011, 2011, 7. [CrossRef]

92. Li, Y.; Zhao, X.; Xu, Q.; Zhang, Q.; Chen, D. Facile preparation and enhanced capacitance of the polyaniline/sodium alginate nanofiber network for supercapacitors. Langmuir 2011, 27, 6458-6463. [CrossRef] [PubMed]

93. Qian, Y.; Wang, T.; Qiu, X.; Zhao, D.; Liu, D.; Deng, Y. Conductivity enhancement of poly(3,4-ethylenedioxythiophene)/lignosulfonate acid complexes via pickering emulsion polymerization. ACS Sustain. Chem. Eng. 2016, 4, 7193-7199. [CrossRef]

94. Zhou, H.; Yao, W.; Li, G.; Wang, J.; Lu, Y. Graphene/poly(3,4-ethylenedioxythiophene) hydrogel with excellent mechanical performance and high conductivity. Carbon 2013, 59, 495-502. [CrossRef]

95. Du, X.-S.; Zhou, C.-F.; Mai, Y.-W. Novel synthesis of poly(3,4-ethylenedioxythiophene) nanotubes and hollow micro-spheres. Mater. Lett. 2009, 63, 1590-1593. [CrossRef]

96. Choi, J.W.; Han, M.G.; Kim, S.Y.; Oh, S.G.; Im, S.S. Poly(3,4-ethylenedioxythiophene) nanoparticles prepared in aqueous dbsa solutions. Synth. Met. 2004, 141, 293-299. [CrossRef]

97. Liu, C.; Cai, Z.; Zhao, Y.; Zhao, H.; Ge, F. Potentiostatically synthesized flexible polypyrrole/multi-wall carbon nanotube/cotton fabric electrodes for supercapacitors. Cellulose 2016, 23, 637-648. [CrossRef]

98. Bidgoli, M.M.; Mohsennia, M.; Boroumand, F.A. Low driving voltage characteristics of polyaniline-silica nanocomposites as hole-injection material of organic electroluminescent devices. Mater. Res. Bull. 2015, 72, 29-34. [CrossRef]

99. Wei, L.; Chen, Q.; Gu, Y. Effects of inorganic acid in dbsa-pani polymerization on transparent pani-sio2 hybrid conducting films. J. Alloys Compd. 2010, 501, 313-316. [CrossRef]

100. Li, J.; Ma, Y. In-situ synthesis of transparent conductive pedot coating on pet foil by liquid phase depositional polymerization of edot. Synth. Met. 2016, 217, 185-188. [CrossRef]

101. Babu, K.F.; Subramanian, S.P.S.; Kulandainathan, M.A. Functionalisation of fabrics with conducting polymer for tuning capacitance and fabrication of supercapacitor. Carbohydr. Polym. 2013, 94, 487-495. [CrossRef] [PubMed]

102. Wilson, G.J.; Looney, M.G.; Pandolfo, A.G. Enhanced capacitance textile fibres for supercapacitors via an interfacial molecular templating process. Synth. Met. 2010, 160, 655-663. [CrossRef]

103. Hepowit, L.R.; Kim, K.M.; Kim, S.H.; Ryu, K.S.; Lee, Y.M.; Ko, J.M. Supercapacitive properties of electrodeposited polypyrrole on acrylonitrile-butadiene rubber as a flexible current collector. Polym. Bull. 2012, 69, 873-880. [CrossRef]

104. Prasanna, B.P.; Avadhani, D.N.; Raghu, M.S.; Kumar, Y.K. Synthesis of polyaniline/alpha-fe2o3 nanocomposite electrode material for supercapacitor applications. Mater. Today Commun. 2017, 12, $72-78$.

105. Lota, K.; Khomenko, V.; Frackowiak, E. Capacitance properties of poly(3,4-ethylenedioxythiophene)/carbon nanotubes composites. J. Phys. Chem. Solids 2004, 65, 295-301. [CrossRef] 
106. Liu, J.; Li, M.; Zhang, Y.; Yang, L.; Yao, J. Preparation and enhanced electrochemical properties of ag/polypyrrole composites electrode materials. J. Appl. Polym. Sci. 2013, 129, 3787-3792. [CrossRef]

107. Zhang, H.; Ren, P.; Wang, C.; Pei, L.; Han, Z.; Fang, C. In situ synthesis and characterization of polypyrrole/graphene conductive nanocomposites via electrochemical polymerization and chemical reduction. J. Macromol. Sci. Part B Phys. 2014, 53, 1116-1127. [CrossRef]

108. Saranya, S.; Selvan, R.K.; Priyadharsini, N. Synthesis and characterization of polyaniline/mnwo4 nanocomposites as electrodes for pseudocapacitors. Appl. Surf. Sci. 2012, 258, 4881-4887. [CrossRef]

109. Lupu, S.; Javier del Campo, F.; Xavier Munoz, F. Sinusoidal voltage electrodeposition and characterization of conducting polymers on gold microelectrode arrays. J. Electroanal. Chem. 2012, 687, 71-78. [CrossRef]

(C) 2018 by the authors. Licensee MDPI, Basel, Switzerland. This article is an open access article distributed under the terms and conditions of the Creative Commons Attribution (CC BY) license (http://creativecommons.org/licenses/by/4.0/). 